\title{
POLEMICS ON INTERFAITH MARRIAGE IN INDONESIA BETWEEN RULES AND PRACTICES
}

\author{
Ermi Suhasti*, Siti Djazimah**, \& Hartini *** \\ *, ** Sunan Kalijaga State Islamic University, *** Gadjah Mada \\ University, Yogyakarta, Indonesia \\ email: ermi.subasti@yahoo.co.id
}

\section{Abstract}

The Indonesian rules on marriage manage that a marriage is required to be one faith marriage, i.e., a man and woman to embrace the same religion, and prohibits interfaith marriage. However, in practice interfaith marriage is concluded and the couple of such marriage struggled to conduct the marriage and to have the marriage legitimized. One of the ways is to propose a designation or decree from the civil court to officially allow them to marry and to mandate the Civil Marriage Registrar to register their marriages. This article discusses the practice of interfaith marriages based on the permission from the civil courts' judges in Surakarta. Deploying the socio-legal approach and based on interviews with some relevant persons and on the observation on a number of civil courts' decrees, this article finds that there are interfaith marriages in Indonesia and interfaith couple struggled to get their marriages officially admitted and legalized by taking the advantage of the legal gap on the issue. This article also argues that there has been divergent legal interpretation within Indonesians which led to legal uncertainty regarding the rules of interfaith marriage in Indonesia. Peraturan tentang perkawinan di Indonesia mengatur pernikahan satu agama. Pernikahan harus antara wanita dan laki-laki Muslim dan larangan pernikahan beda agama. Banyak praktik pernikahan melakukan ikatan beda agama. Pernikahan ini diilakukan para pasangan dengan berupaya keras dengan cara apapun untuk dapat menikah secara formal. Salah satu cara dengan memohon ïin melalui putusan Pengadilan Negeri. Pengadilan 
Ermi Suhasti, et al.

memberikan ijin pernikahan beda agama dan mandat kepada pegawai Pencatat Sipil untuk dicatatankan sebagai pernikahan. Artikel ini mengkaji praktik pernikahan beda agama melalui penetapan Pengadilan Negeri di Surakarta. Penelitian ini menggunakan pendekatan sosiologi bukum dengan wawancara dan analisa terhadap beberapa penetapan dalam penyusunan paper. Artikel ini membahas pernikahan beda agama yang dilakukan masyarakat Indonesia yang mengalami kesulitan dan mengupayakan secara keras cara dalam pernikahan beda agama. Argumen lain artikel ini adalah pola penafsiran hukum yang beragam dari pasal-pasal Kompilasi Hukum Islam dan Undang-Undang Perkawinan. Tafsir ini membawa pada ketidakmapanan dan ketidakpastian bukum terkait dengan ketentuan pernikahan beda agama di Indonesia.]

Keywords: polemic, interfaith marriage, rules, practices, legitimacy, determination.

\section{A. Introduction}

The purpose of marriage is to bring harmony and happiness in life. In order to achieve this, human being requires regulations or rules in his life, one of them is the rule of marriage. Rules of marriage had been regulated in Law No. 1 of 1974 on Marriage (UUP) and the Presidential Decree (Inpres) no. 1 of 1991 about the Compilation of Islamic Law (KHI). UUP in the Article 2, paragraph (1) states that marriage is considered legitimated if it follows a particular religion. ${ }^{1}$ This article provides stipulation that a marriage is legitimated if it follows a certain religion. Therefore it is impossible for Muslims to marry non-Muslims by following the religious law of the non-Muslims or a non-Muslims marry Muslims by following the Islamic law or that marriage follows the law of the two religions at once.

The stipulation of legitimated marriage can also be seen in KHI

${ }^{1}$ Law of the Republic of Indonesia on Marriage, 1/1974 Article 2 paragraph 1. States "A marriage is legal, if it is conducted based on law of each religion and faith. Explanation of this article states, "by the formulation of article 2: 1, there is no marriage outside the respective regulation of religion and faith, according to Constitution of 1945. The regulation of religion and faith here is including the legislation for those religion and faith as long as it is not contradictive with or set in this Law. 
which requires a marriage of the same religion, a Muslim man should marry a Muslim woman and vice versa. The articles are Article $40 c{ }^{2}$ article $44^{3}$ and article $61 .^{4}$ The stipulation of those articles requires a marriage in the same religion between Muslim man and Muslim woman and it is not allowed to have a marriage of couples who have different religions. ${ }^{5}$

A number of researchers discuss the issue of interfaith married. Gianluca P. Parolin discusses the interfaith marriages and Muslim communities in Scotland. ${ }^{6}$ He explores the adaptation and transmigration of Islamic regulations on interfaith marriages among the Muslim communities in Scotland. Islamic impediments to marriage by different faith have somehow guaranteed the religious endogamic principle in Muslim-majority contexts. What happens when borders are crossed and South Asian communities find themselves in a Scottish context? In order to follow this adaptation and transmigration, we need to embark on a journey through time and space. He suggest to depart from the single rule on interfaith marriages produced by modernity.

Alex Minichele Sewenet, et al., argued that Muslim women are not allowed to marry other than Muslim men. ${ }^{7}$ This restriction is made

2 Presidential Instruction of Compilation of Islamic Law, 1/1991 Article 40c. States, "it is forbidden to conduct marriage between a man and a woman with certain condition of: (c) woman of non-Islam."

3 Ibid. Article 44. States, "A muslim woman is prohibited to marry with nonmuslim man."

4 Ibid. Article 61. Article $61 \mathrm{KHI}$ relates to the prevention to conduct marriage, the article states "being different should not be a reason to prevent marriage, unless it is due to different faith ikbtiläfu al-den.

5 The explanation of Article 1 UU No. 1/1974 mentions, "Having Pancasila as the basis of the State, in which the first Sila is Believe in the One and Only God, marriage has a close relationship with religion/spiritual, so that it doesn't only consist of physical element but also spiritual element. Forming a happy family is closely related to heredity which also become the purpose of marriage, in which caring and education have become the right and obligation of the parents.

${ }^{6}$ Gianluca P. Parolin, "Interfaith Marriages and Muslim Communities in Scotland: A Hybrid Legal Solution?”, Electronic Journal of Islamic and Middle Eastern Law (EJIMEL), vol. 3, no. 17 (2015), pp. 83-96.

${ }^{7}$ Alex Minichele Sewenet, Fasil Merawi Tessagaye, and Getnet Tadele, "Interreligious Marriage: Social and Religious Perspectives", Imperial Journal of Interdisciplinary Research, vol. 3, no. 6 (2017), pp. 355-62. 
due to the fear that children of interreligious spouses might follow the religions of their father due to the jurisdiction Islamic law vests up on the husband over the wife on matters of children especially in nationality and marriage. Islam in general does not appreciate the marriage between Muslims and Non-Muslims. Instead conversionary marriage is highly encouraged. Any attempt of Muslims to marry from non-Muslims is considered as unlawful and is highly condemned by Islam. The exception is in case of conversion. Muslims can marry from any religious group if his/her partner is willing to convert to Islam. But the marriage could not be blessed and in effect until the conversion is realized.

The study of the issue of interfaith marriages in Indonesia has been also done in a number of works. Indrayanti, et al. argued that the constitutional rights of marriage entailed the obligation to respect the constitutional rights of other people and thus to avoid any conflicts in the implementation of those constitutional rights, it is necessary to have a regulation on the implementation of constitutional rights conducted by the state. ${ }^{8}$ It is further submitted that without legalizing interfaith marriage, there will be children status issue and heritage issues in the future. Thus, it is argued that the principle of interfaith marriage does not contradict the principles contained in the constitution with regard to the rights to form a family and to freedom of religion. Hartini and Ermi discusses the shift in the sacred value of marriage which has become a principle of marriage law in Indonesia with the determination of the court. The recording is not required to perform a religious ritual as determined by the judge in Surakarta District Court and the recording done by Dinas Kependudukan dan Catatan Sipil Surakarta. ${ }^{9}$

Euis Nurlaelawati observes how Muslim judges resolve familial cases related to apostasy at court and to what extent their legal decisions

${ }^{8}$ Kadek Wiwik Indrayanti et al., "Juridical Implications of the Legal Norm Void of Interfaith Marriages in Indonesia”, Brawijaya Law Journal, vol. 4, no. 1 (2017), pp. 129-43.

9 Ermi Suhasti and Hartini, "Shifting Meaning of the Sacred Value of Marriage: Study on the Practice of Interfaith Marriage through the Establishment of the District Court", presented at the International Conference Legal Reform in Indonesia: Towards Justice (Yogyakarta, 6 Sep 2017). This conference held by Universitas Gadjah Mada in cooperation with Universiteit Leiden, the University of Melbourne, the University of Sydney, and KITLV. 
on these issues are shaped by the majority of religious authorities' and their own understanding of the Islamic doctrine of religious protection. ${ }^{10}$ It argues that while the Islamic state law has sought to move away from the classical religious rules in the administration of apostasy as to protect human rights, judges find it difficult to renounce the dogma that Muslims must protect their religion from any possible danger other groups of religion would create and that the religious protection is often in conflict with the realization of the right to religious freedom. Ratno Lukito argues that the Law No. 1 of 1974 appeared to ignore a number of issues dealing with interpersonal relations involving people of different religious backgrounds. ${ }^{11}$ Although on the basis of the constitution, religions and their values were recognized as valueable sources of family law, in practice the marriage law failed to do just this. The state's recognition of religious pluralism did not lead to more explicit rules on how to deal with plurality in the domain of personal law. One of the biggest issues in this respect was the complicated problem of interfaith marriage, that is, marriages between Muslim and non-Muslims. The cases of interfaith marriage conflicts have been brought to the court. The legal problems of this case be explained in order to show the real nature of the conflict in Indonesia, especially within the framework of the state's program of legal nationalization.

The regulation enacted in 1991 also precludes and prohibited people of different religions to marry. However, it doesn't mean that the practice of interfaith married stops. Some couples did interfaith married after $1991 .{ }^{12}$

10 Euis Nurlaelawati, "For the Sake of Protecting Religion: Apostasy and its Judicial Impact on Muslim's Marital Life in Indonesia", Journal of Indonesian Islam, vol. 10, no. 1 (2016), pp. 89-112.

11 Ratno Lukito, "The Enigma of Legal Pluralism in Indonesian Islam: The Case of Interfaith Marriage", Journal of Islamic Law and Culture, vol. 10, no. 2 (2008), pp. 179-91.

12 Ermi Suhasti, "Harmoni Keluarga Beda Agama Di Mlati, Sleman, Yogyakarta”, Asy-Syir'ah, vol. 45, no. 1 (2011), pp. 1233-54. This research showed that during 8 years (2000-2008) there were 99 cases of interfaith marriage in the village of Sinduadi and Tirtoadi, Mlati, Sleman, Yogyakarta. 
The vacuum of law $^{13}$ related to the interfaith has led to the practice marriage of people with different religion especially among the Muslims. These interfaith couples try to anticipate the prohibition of law by following or submitted to one of their spouse religion. ${ }^{14}$ For example, interfaith couples between Muslim woman and Catholic man, the man should convert to Islam first by changing their identity in the citizen ID card so that they can register the marriage in the Religious Affairs Office. Similarly, for a Muslim man and a Catholic woman who would get married in the Christian tradition in the Church and register their marriage in the Civil Registry Office should do a conversion in which the man changes his religious identity on the citizen ID card. ${ }^{15}$

Getting married is exactly a human right issue. There is no law in Indonesia that forbids people to get marry. On the other hand, the State also has the authority and duty to regulate its citizens, including marriage, therefore the stipulation of marriage law is coercive (dwinged recht). For a religious reason, couples of different religions often try various ways to get their marriage legitimacy. Lately, they apply to have a decree from the State court to conduct interfaith marriage. This paper intends to analyze the polemic of interfaith marriage in Indonesia particularly the practice of interfaith marriage through the decree of the State court as well as the dichotomy and inconsistencies due to this practice.

\section{B. Interfaith Marriage in Normative Perspective}

Marriage is a special event in the stage of human life. Some people

13 The term of vacuum of law came out because the marriage law in Indonesia doesn't particularly regulate a case of interfaith marriage. See "Law of the Republic of Indonesia on Marriage", Article 2, paragraph 1.

14 Suhasti, "Harmoni Keluarga Beda Agama di Mlati, Sleman, Yogyakarta". See Sri Wahyuni, "Pelaksanaan Perkawinan Campur Beda Agama antara Warga Melayu Malaysia dan Dayak Kalimantan di Daerah Perbatasan Sambas Kalimantan Barat Antara Living Law dan Hukum Positif Indonesia", Al-Ahwal: Jurnal Hukum Keluarga Islam, vol. 9, no. 1 (2017), pp. 31-46.

${ }^{15}$ Interview on five interfaith couples who have married over twenty to thirtyfive years in the sub-district of Melati in 2009. it is described that these couples get married twice, at KUA in the morning, and at KCS in the afternoon. See for full at Ermi Suhasti, Harmoni Keluarga Beda Agama, Research Report (Yogyakarta: Lemlit UIN Sunan Kalijaga, 2009); Suhasti, "Harmoni Keluarga Beda Agama di Mlati, Sleman, Yogyakarta". 
even consider it as a sacred event, similar with life and death. Hence, every religion has its own rules in detail how this event must be. With those rules every marriage and family life is supposed to be in the right path. The development of technology and communication has made people easily communicate with the same or different religion. As a result, interfaith marriage is seen very common nowadays. This reality in fact causes complicated problems in their life including a problem of interfaith marriage. It still becomes a contradiction for positive law experts and normative law experts (figh) in Indonesia.

Islam gives guidance for every follower both in the aspect of $i b a d a h$ and mu'amalah. Islamic Sharia manages the whole aspect of life including marriage which is intended to be beneficial for mankind (the concept of maqasid ash shari'a). In this section we explore the issue of interfaith marriage in the perspective of Islam law.

Literally there are at least three verses of the Qur'an which clearly mention interfaith marriage. ${ }^{16}$ Those are Al-Baqarah: 221, Al-Maidah: 5, and Al-Mumtahanah: 10. Most Fuqaha' have agreed that Muslim women are not allowed marry non-muslim men, either unbelievers, infidels or ablul kitab. ${ }^{17}$ Literally, al-Baqarah: 221 says the prohibitions for believers not to marry idolaters (notably the musyrike. ${ }^{18}$ Meanwhile, Quran, 5:5 says that there is a possibility for Muslim men to marry a woman of $\mathrm{Abl}$ alKitab; whereas Quran, 60:10 talks about a prohibition of Muslim women to marry infidel men. The problem here is a marriage between a Muslim man and a woman of Abl al-Kitab still allowed or not?

Ulama interpretation (mufassirin) has a different view on the $A b l$ al-Kitab. Ibn Kathir in his book Tafsir al-Qur'an al-Adzim explained that after the revelation of Ayah 5 of Surah al-Maidah, there were many sahabat (Prophet Muhammad companion) married with women of abl al-Kitab, so, this seems to counter Quran, al-Baqarah: 221. It shows that

16 Fuad Mustafid, "Perkawinan Beda Agama dan Kebebasan Individual Manusia dalam Islam: Perspektif 'Teori Naskh' Mahmoud Muhammad Thaha”, Musãwa Jurnal Studi Gender dan Islam, vol. 10, no. 2 (2011), pp. 229-48.

17 M. Quraish Shihab, Tafsir AlMisbah, vol. 3 (Jakarta: Lentera Hati, 2006), p. 30.

18 Abu'l-Fida Isma'il Ibn Katsir, Tafsir Al-Qur'an Al-Adzim, vol. 1 (Beirut: Dar al-Fikr, 1997), p. 296. 
marrying kitabiyah women are allowed based on al-Maidah: $5 .{ }^{19}$ This is also stated by Imams Mazhab that marrrying an abl al-kitab woman is permitted. ${ }^{20}$ Regarding to the kitabiyah woman who are allowed to marry with a Muslim man, there are two different opinions. First is a kitabiyah woman (followers of the Torah and the Gospel) is allowed to be married, although there is difference in faith. Second, the kitabiyah women are allowed to marry, while the kitabiyah woman whose religious teachings and belief have been distorted are forbidden to be married. It is because of their idolatry; and idolater women are forbidden to be married (their polytheism is affirmed in the Qur'an, 9: 31). ${ }^{21}$

Concerning the interfaith marriage in the present context of Indonesia, MUI issued a fatwa in 1980, which forbids the marriage of Muslim men with non-Muslim women despite the status of being an abl al-Kitab. ${ }^{22}$ The fatwa is not clearly based on the 'illat that religious believers who once declared by God as the Abl al-Kitab who are allowed to be married, at the present time belong to the polytheists and infidels, at least textually. What mentioned in the fatwa is that the mufsadat (of interfaith marriage) is more than its maslahat, and this clause is not followed by any further interpretation or explanation. Based on the description of the ulema, addressing the legal issues of marrying kitabiyah woman, there are at least two different opinions ${ }^{23}$, namely, the agreed group, and the disagreed group who forbid it as sadz adz-dzaria'ah.

19 Abu'l-Fida Isma'il Ibn Katsir, Tafsir Al-Qur'an Al-Adżim, vol. 2 (Beirut: Dar al-Fikr, 1997), p. 25.

20 Abdurrahman al-Jaziriy, al- Fiqh "ala Mazahib al- Arba" ah, vol. 4 (Beirut: Dar al- Ihya al- Turas al- 'Arabi, 1969), p. 75.

21 Wasman and Wardah Nuroniyah, Hukum Perkawinan Islam di Indonesia: Perbandingan Fiqib dan Hukum Positif (Yogyakarta: Teras, 2011), pp. 283-4. Interpretation of surat at-Taubah (9), 31: “They take their priests and their anchorites to be their lords in derogation of Allah, and (they take as their Lord) Christ the son of Mary; yet they were commanded to worship but One Allah. there is no god but He. Praise and glory to Him: (Far is He) from having the partners they associate (with Him)".

22 This fatwa issued at 1 Juni $1980 \mathrm{M} / 17$ Rajab $1400 \mathrm{H}$ after having National Meeting II (Munas II) from 26 Mei-1 Juni 1980 in Jakarta. See MUI, Himpunan Fatwa MUI Sejak 1975 (Jakarta: Erlangga, 2011), pp. 43-5. About the number of the fatwa is not mentioned in the book.

23 We (wittingly) make two classifications to get a clearer explanation than what said in Wasman and Nuroniyah, Hukum Perkawinan Islam di Indonesia, pp. 284-94. 
The group that justifies interfaith marriages between Muslim men and Abl al Kitab women (Jews and Christian) argues the claims based on: several verses of the Qur'an indeed distinguish between idolaters and the Ablal-Kitab (Jews and Christians). ${ }^{24}$ Idolaters mentioned in 2: 221 are not the Jews and the Christians, but Arabs who do not have a Holy Book. The prohibition to marry the idolaters is because there was a worry that they would fight against Muslims. It is also because the disbelievers are not a group of ablal-dzhimmah. The fundamental reasons regarding the possibility of marrying a kitabiyah woman is Quran, 5: 5. A verse revealed after Quran, 2: 221, explicitly allows Muslim men to marry kitabiyah women. Thus, verse 5 of the surah of al- Maidah seems to underline the previous verse $(2: 221){ }^{25}$

The group that completely prohibits this interfaith marriage, adhere to surah Al Baqarah: 221, "And do not marry idolater women until they embrace the faith" and surah al- Mumtahanah: 10, "And do not stick to the rope (marriage) with women of infidels". The second verse clearly forbids women to marry idolaters, so that Muslim men are forbidden to marry non-Muslim women; meanwhile the Abl al- Kitab including pagan idolaters are also considered as a disbeliever since Jews worship 'Uzer and Christian groups worship 'Isa ibn Maryam. The Abl al-Kitab women mentioned in Surat 5: 5 is meant women who believe in the Prophet or

${ }^{24}$ For instances, see Muhammad Rasyîd Ridha, Tafsir al-Manar, vol. VI, 1st edition (Beirut: Dâr al-Kutub al-'Ilmiyyah, 1947), p. 148; Ahmad Mustafa Maraghi, Tafsîr al-Marâghi, vol. VI, 1st edition (Cairo: Mathba'ah al-Halabiy, 1946), p. 59. Even both of these ulama give notes that the women who will be married must be kind women (al-mubshanât) and the man must have strong faith. See also Hamka, Tafsir AlAz̧har, vol. V (Singapura: Pustaka Nasional Pte Ltd, 2003), p. 257. The notes given by those Ulama indirectly relate to the third group as what said by Wasman and Wardah Nuroniyah as the other groups. They are those who allow marriage between Muslim men and non-Muslim women, but they tends to forbid it as a preventive act to anticipate a risk that may happen caused by the marriage, for instance in the form of apostasy and domestic conflict as a result of ideological conflict and creed. Thus, interfaith marriage potentially leads to conflict or will be a source of conflict that could threaten the unity and happiness of the household as well as the Islamic faith.

${ }^{25}$ See Muhammad 'Ali al-Shâbûni, Tafsîr Âyât al-Ahkâm, vol. I (Cairo: Dâr al-Shâbûni, 2007), p. 204; 'Abd Allāh ibn Aḥmad Ibn Qudāmah, Al-Sharh al-Kabîr 'alâ Matn al-Mughnî, vol. VII (Beirut: Dār al-Fikr, 1984), p. 500. 
a Holy Book sent by Allah SWT. ${ }^{26}$

Considering the negative effects (disadvantages) of interfaith marriage which is greater than the positive impact (beneficiaries), the Indonesian Ulama Council, as mentioned above, has issued a fatwa/ decree that prohibits interfaith marriage, both between Muslim men with non - Muslims women as well as between Muslim woman with a non - Muslim man. ${ }^{27}$

There is in fact dissenting opinions among the experts and ulama concerning the marriage status of interfaith marriage. Literally Quran, 2: 221 prohibits a Muslim man to marry a non-Muslim woman and Muslim woman to marry a non-Muslim man. While surah Al Maidah: 5 allows a Muslim man to marry a woman of Abl al-Kitab; and surah Al Mumtahanah: 10 talks about a prohibition of a Muslim woman to marry a disbeliever (man). Furthermore, Khoiruddin explains that regarding to nash of these verses, "ulama can be divided into two: First, some 'ulamas interpret the texts with a textual and literal understanding. Based on this understanding, interfaith marriage is absolutely prohibited (theology). Second, the other 'ulamas understand that the interpretation of the texts about interfaith marriage has a temporal nature and contextual understanding. Thus, an interfaith marriage is not completely prohibited, but it depends on its context. As mentioned by Khoiruddin Nasution. ${ }^{28}$

Hence, a normative perspective of the registration of interfaith marriage is similar; it follows the understanding of the legal status. Those who understand textually will likely say that interfaith marriage is not necessary to register, while those who understand contextually will likely say that interfaith marriage can be registered in order to have a legal certainty.

\section{Debates on and Practices of Interfaith Marriage in Indonesia}

One of the ways employed by interfaith marriage couples who want

26 This group actually consists of the institutionalized ulama such as MUI by its fatwa as mentioned.

27 Fatwa MUI Nomor 4/MUNAS VII/MUI/8/2005.

${ }^{28}$ Khoiruddin Nasution, "Pencatatan Perkawinan Beda Agama: Tinjauan Normatif", presented at the National Seminar of Contemporary Law of Islamic Family in Indonesia (Yogyakarta, 2015). 
to marry in Indonesia is by converting to the religion of their couples and following the rule of the marriage of their couples. After marriage, the wife or husband may have new religion or they may get back to their former religion. This family is called an interfaith spouse. Prof. Wahyono Danabrata, calls this as a 'law gap', temporarily follows the rules of one of the religions. ${ }^{29}$

Religion and law experts in Indonesia have different views about this. Quraish Shihab's says that the law of interfaith marriage should follow one of the religious law of the spouse. Marriage must be bound by the principle of the sameness of religion and faith. On the interfaith marriage there must be a guarantee from each religion to respect the religion of their spouses. ${ }^{30}$

Judicially, interfaith marriage causes problem because there are no rules how to marry someone with different religion. Though this kind of marriage is not legally allowed, in practice, the registrar still registers their marriage without looking further the legal status of the spouse's marriage. It is done because there is a marriage registry from the church and a decree from the State court. ${ }^{31}$ Interfaith marriage is normatively

${ }^{29}$ Though forbidden, interfaith marriage still happens. Interfaith couples have done many things in in order to get the State legitimacy. In a seminar in Depok, a Professor of Civil Law of Universitas Indonesia, Wahyono Darmabrata, elaborated four ways that are used by interfaith couples in order to get married. Those four ways are; asking for the judicial decree, conducting marriage on each religion, following (temporary) one of the couple religion and getting married abroad. See "Empat Cara Penyelundupan Hukum Bagi Pasangan Beda Agama”, hukumonline.com (2006), https:// www.hukumonline.com/berita/baca/hol15655/empat-cara-penyelundupan-hukumbagi-pasangan-beda-agama, accessed 14 Aug 2017.

30 This opinion is in line with the statement of Father Andang Binawan SJ., a Lecturer of Driyarkara Philosophy University. Father Andang explained that the law of Catolic Church allows Interfaith Marriage as long as the bride or groom would promise to conform to the law of Catholic Marriage such as; monogamous marriage, not divorce for a lifetime, and let their couple to keep his/her faith as a Catholic. See 'Dialog Lintas Agama', the collaboration of Sanata Dharma University published by Kanisius, Yogyakarta, June 20th, 2009.

31 Based on the previous research on May, $2^{\text {nd }} 2014$, a staff of Civil Registrar Office in Yoyakarta said that the state doesn't mean to not accommodate interfaith marriage. Because every marriage in Indonesia is based on religion's law of marriage, the forbidden thus comes the rules of the religion itself, not from the civil law. It also means that as long as religion does not legalize the interfaith marriage, the civil registrar 
illegal but procedurally it can be accepted by most society.

\section{Judicial Review and Human Rights}

Some of the above facts intrigue students of UI (Indonesia University) to take a legal action on this Marriage Law (Undang-Undang Perkawinan) to the Constitutional Court, because people need a legal certainty concerning an interfaith marriage. A female student and four alumni of Faculty of Law UI on Wednesday (4/9/2014) in the Constitutional Court defined Article 2 section 1 UU No. 1/1974 which concludes, "a marriage is legitimated if it is based on a religious law and faith (Pernikahan adalah sah, apabila dilakukan menurut bukum masing-masing agamanya dan kepercayaan itu)". This has made an uncertainty of law for those who will marry but have different religion in Indonesia. Constitution should guarantee a certainty of law. As a result, the society of Indonesia who are going to marry through this way tend to eschew the law. That is by getting married abroad or using a certain cultural law. They argue that it is time for the government not rigidly bounded by the values of religion and the faith of each society. Thus, let the society choose their own decision or their own marriage based on their own faith, including to follow or not the teachings of their own religion. For this reason, Anbar with the other four colleagues from UI Law Faculty alumnus; Damian Agata Yuvens, Rangga Sujud Widigda, Varida Megawati Simarmata, and Lutfi Sahputra request CC, to declare the article 2 par. (1) Law No 1 year 1974 concerning marriage are contradictive to article 27 par. (1) and article 28B par. (1), article 28D par. (1) article 28E par. (1), article 28E par (2), article 28I par (1), and article 29 par. (2) The Constitution of Republic of Indonesia 1945 since it does not have a binding law. ${ }^{32}$

After this action, the clergies or religious leaders inquired the judge of the Constitutional Court to reject the material review of interfaith marriage. Indonesian Council of Ulama (MUI) forbids interfaith marriage

will not register it.

32 See for complete at Febrian, "Gugat UU Pernikahan ke MK Agar Menikah Beda Agama Ada Kepastian Hukum” - Kompas.com, https://nasional.kompas.com/ read/2014/09/04/19394581/Gugat.UU.Pernikahan.ke.MK.Agar.Menikah.Beda. Agama.Ada.Kepastian.Hukum, accessed 4 Sep 2014. 
because it is basically not allowed in almost every religion..$^{33}$ At first, the clergies and ulama agreed to reject interfaith Marriage; ${ }^{34}$ however, it changed. The Communion of the Churches (Persekutuan GerejaGereja) considered the prohibition of interfaith marriage as violation of the human rights. Indonesian Buddhist Representative (Perwalian Umat Buddha Indonesia/Walubi) agreed that interfaith marriage cannot be banned by the rules. ${ }^{35}$ This phenomena certainly causes anxiety among the clergies/ulama, intellectuals or law experts. ${ }^{36}$

Since legally set up as a National Marriage Law (Hukum Perkawinan Nasional) on January, $1^{\text {st }} 1975$, UU No 1 year 1974 (It was then called as Marriage Law/Undang-Undang Perkawinan), was one of a legislation product of post-Indonesian Independence that has a long range of validity. It is a fact that since this law was constituted, it has never been changed or replaced, though there have been always any polemics, criticisms, and proposal of changes on it. Criticisms and proposals of amendments are commonly directed to protect marginal society and other minorities on the name of equal right (the human right).

One Polemic that emerges is about interfaith marriage. In the

33 It was said by Farida Prihatini, the lecturer of Islamic Law from the Faculty of Islamic Law, Universitas Indonesia. She explained that people always search for chances. Interfaith marriage is considered as illegal, adultery, and there is no inheritance. The child also only has legal relation with the mother. In 'Dialog Antar Agama', Yogyakarta on June, 20th 2009.

34 On September, 13th 2014; MUI and other religious institution seek for an agreement about interfaith marriage. The discussion that was held by MUI was attended by Walubi (the representative of Umat Buddha Indonesia), PHDI (Parisada Hindu Dharma Indonesia), PGI (Persekutuan Gereja-Gereja Indonesia), KWI (Konferensi Waligereja Indonesia), and Matakin (Majelis Tinggi Agama Konghucu Indonesia). PGI agree for the judicial review of article 2 section (1) UU Number 1 Year 1974 about the forbiddance of Interfaith Marriage. See "Kompak Tolak Nikah Beda Agama", Jpnn.com, https:/ / www.jpnn.com/news/kompak-tolak-nikah-beda-agama, accessed 13 Sep 2014.

35 For more, see "PGI Anggap Larangan Nikah Beda Agama Melanggar HAM", www.jpnn.com (2014), https:/ / www.jpnn.com/news/pgi-anggap-larangan-nikah-bedaagama-melanggar-ham, accessed 5 Nov 2014.

36 See M. Karsayuda, Perkawinan Beda Agama: Menakar Nilai-Nilai Keadilan Kompilasi Hukum Islam (Yogyakarta: Total Media, 2006), p. 6; Mohammad Monib and Ahmad Nurcholish, Kado Cinta Bagi Pasangan Nikah Beda Agama (Jakarta: Gramedia Pustaka Utama, 2008), p. 41. Compare with, Nasrul Umam Syafi'i and Ufi Ulfiah, Ada Apa Dengan Nikah Beda Agama? (Jakarta: Qultum Media, 2004), p. 85. 
writer's opinion, the debates about interfaith marriage in the perspective of positive law are in fact not only whether interfaith couple can marry or not, ${ }^{37}$ but it is more about what they should do if people with different religion meet and want to marry. It is because marriage is an individual matter. One can marry with whomever they want and a choice can not be forced. Though the legalization of a marriage is determined by a religious law, an understanding of these religious teachings exactly depends on each individual being. No one can force his will to anyone else. In fact, an obedience of somebody toward his/her religion will influence his/her behavior including when she/he has a couple and gets married. A good understanding of religion will bring a person into an obedient person that he/she will do the duties given by the religion and keep away from the thing forbidden by it.

\section{Interfaith Marriages by the State Court's Decree}

The practice of interfaith marriage through the decree of the State Court, begins when a couple of different religions intend to get married, and they come to the Civil Registry Office (now the Department of Population and Civil Registration/Dispendukcapil) to register their marriage. Dispendukcapil will usually issue a rejection because one of the couple is a Muslim. Supposedly, if one of the couple is a Muslim, then it becomes the domain of the Registrar of Marriage in the Office of Religious Affairs (VAT-KUA) to register and record the marriage. This can be seen in the Stipulation of the District Court of Surakarta No. 92/Pdt.P/2010/PN.Ska., where a man with the initial GC (Christian) intends to marry a woman named AS (Muslim). However, they could not be able to realize their dreams, due to the rejection of registration by Dispendukcapil of Surakarta.

After obtaining a rejection of marriage registration, GC and AS proposed a request to the District Court Surakarta to get a license to conduct an interfaith marriage which is scheduled to be held at the Office of Population and Civil Registration of Surakarta. In this case, each party insisted on not to follow his/her partner's religion, or remain to embrace his/her own religion. The Christians bridegroom would not carry out the marriage procession according to Islam. Similarly, the Muslim bride

37 Though forbidden, in fact there are a lot of interfaith marriages. 
did not want to have a marriage procession based on Christianity.

A permit application of interfaith marriage by GC and AS was decided on June $28^{\text {th }}, 2010$ by the Single Judge which was open for public. The verdicts are as follows: grant the petition of the Applicants, give a permission to the applicants to carry out the interfaith marriage in the office of Population and Civil Registration Surakarta, order the registrar of marriage officer at the office of Population and Civil Registration Surakarta to conduct a marriage between Applicant I (GC) as a prospective husband, with the Applicant II (AS) as the prospective wife, give orders to the employee of Population and Civil Registration Surakarta to do the registration of interfaith marriage of the Applicants on the Marriage Registration Register, and The cost of this application is Rp. $86,000,-$ and it was charged to the applicants.

These determinations raise questions and confusion, why a proposal of interfaith marriage is granted when it is normatively forbidden. It is because according to the Quran, a Muslim woman is forbidden to marry to a non-Muslim man. Similarly, refer to the provisions of Article 8 (f) "a marriage is prohibited if their relationship is forbidden by religion, or other applicable regulations". But it was the verdict of the Judge. As he argues, according to the Marriage Law, the difference of religion should not become a barrier of a marriage. Another consideration is that the Marriage Law is seen to have no regulation concerning the interfaith marriage.

In general, when a marriage is registered in Dispendukcapil, it is mentioned that each marriage should have a marriage certificate or a signed remark from the religious leader that states that there is a marriage. However, concerning interfaith marriage, there is a different approach compared with marriage in general (marriage of the same religion). Requirement of interfaith marriage does not demand any religious rituals. The head of Population and Civil Registration Surakarta, Suwarta, states that the interfaith marriage registration in Dispendukcapil Surakarta, doesn't require a proof which states that religious rituals have been implemented. Hence, the stipulation is seen sufficient, ${ }^{38}$ (here, there is possibility that

38 Suwarta, "Pandangan Praktisi Terhadap Pencatatan Perkawinan Beda Agama", Pandangan Terhadap Polemik Perkawinan Beda Agama (Yogyakarta, 10 Oct 2015). 
any parties still perform religious procession). ${ }^{39}$ This was confirmed by the statement of Ms. Esti Pratiwi. As the head of Marriage and Divorce Division, Department of Population and Civil Registration Surakarta, she states that in carrying out the task of registration of interfaith marriage, Dispendukcapil related it to the provisions of Adminduk Law, Article 35 letter $\mathrm{a}$, which requires a stipulation from the court. So, the requirement of marriage registration Dispendukcapil Surakarta, require proof of decision from of the District Court if a marriage was performed by parties of different religions.$^{40}$ It is assumed that by having the State Court Decision, the rite of religion or belief is no longer considered as a requirement.

It is further mentioned that there is no verification on the implementation of religious rituals on interfaith marriage because Dispendukcapil bases it to the court decision. Concerning the court decision, Dispendukcapil is positioning itself as the institution which is obliged to obey any forms of decision that has been issued by the court because the court decision should be right and respected. In such situations, Dispendukcapil also acknowledge the interfaith marriage after it obtains a legal determination from the courts. ${ }^{41}$ In other words, when Dispendukcapil registers the marriage, especially interfaith marriage, a legal determination from the District Court will substitute the evidence of religious marriages (religious procession) from a place of worship, or religious leaders. The registration of interfaith marriage is usually carried out by the bride and groom at the office of Dispendukcapil in Surakarta. Interfaith marriage will be officially recorded in the marriage certificate which had previously been prepared for it by the marriages registrar employees signed by: the bride and groom, two witnesses, and marriage registrar officer of Dispendukcapil.

With the signing of the marriage certificate, the marriage has been officially recorded. The signed certificates were made into two (2) copies, the first piece was kept by the employee of Marriage Registrar or in the office of Dispendukcapil and the second piece was kept by the Clerk of

\section{Ibid.}

40 Novina Eky Dianti, "Sinkronisasi Peraturan Perundang-undangan Tentang Pencatatan Perkawinan Beda Agama di Kota Surakarta”, Master's Thesis (Yogyakarta: Universitas Gadjah Mada, 2016).

${ }^{41}$ Suwarta, "Pandangan Praktisi Terhadap Pencatatan Perkawinan Beda Agama". 
the Court, in the registry office, which in this case, the District Court of Surakarta. The husband and wife were given a copy of marriage certificate signed by the Head of Surakarta Dispendukcapil.

Procedure and flow of the implementation of interfaith marriage through the the district court, as happened in the District Court and Dispendukcapil Surakarta can be illustrated as followed: ${ }^{42}$

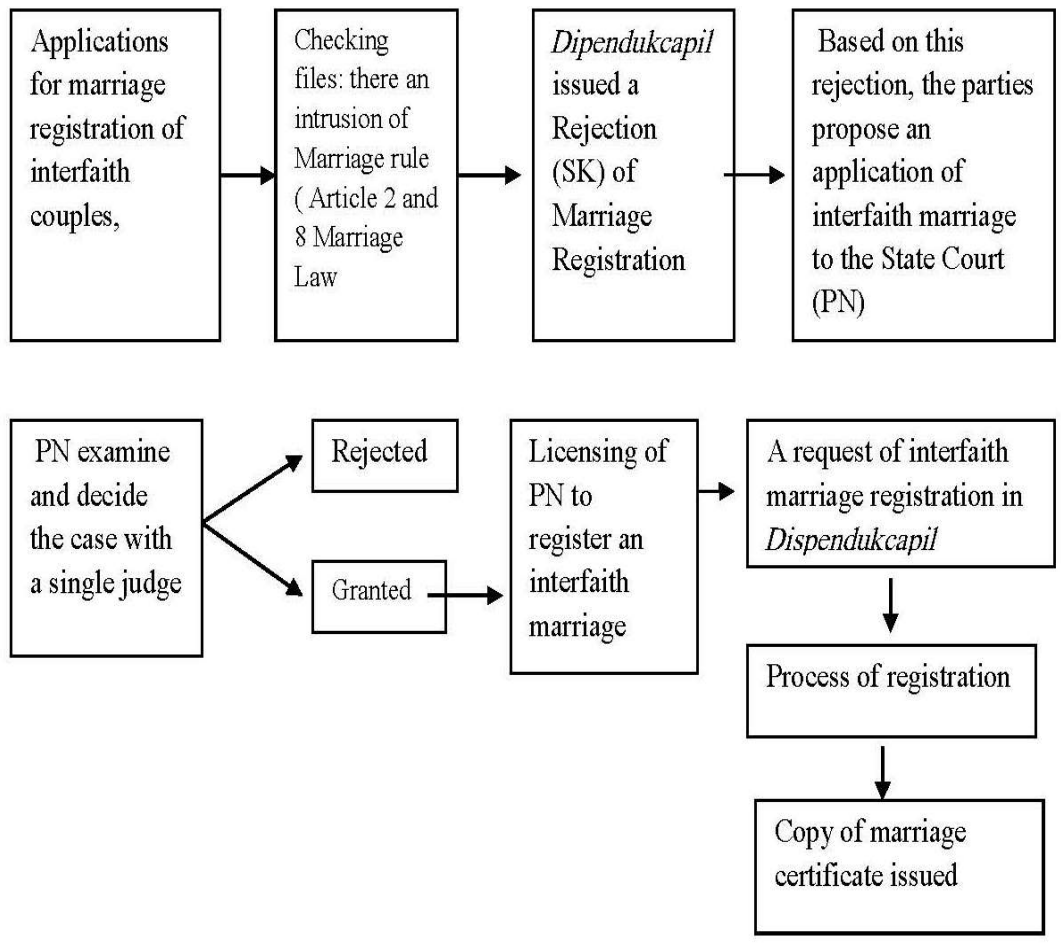

\section{The Attitude of Muslim Society Act toward Marriage Act}

The increasing number of interfaith marriages through legislation of the State Court happened after the legislation of Law No. 23 year 2006 for the Population Administration. Through its Article 34 and 35, this law gives possibility for interfaith couple to be registered by the court. Here, it doesn't mean that they get married in the State Court. The Court only gives permission instead of marrying the interfaith couple off. The problem is then there is a vacuum of law for couple who want to get

42 Source: Secondary Data of Dinas Kependudukan dan Catatan Sipil Surakarta 2015 and other primary data that have been analyzed. 
married in a different religion especially the way of how that marriage should be done, so they have a difficulty in getting the marriage certificate.

Here, there is a dilemma when the law of marriage is included in the private area with such coercive rules and deal with the public rules as the law of Administration of Population was legislated. On one hand, the nation wants any marriages to follow any rules, both nation and religious law; on the other hand, there are substantive norms that forbid certain acts such as interfaith marriage. Thus, it seems that the nation is not able to give the solution. On its substance aspect, interfaith marriage is in the authority of the Marriage Law/UUP. On other words, Marriage Law should deal with anything related to marriage including interfaith marriage. In addition, UU No. 23 year 2006, with all the changes made, has the authority in registering common legal acts that experienced by society or citizens. That is why, seen from it specialty, Marriage Law should more specifically give control over marriage. With this, Les specialis derogate legi generali can be applied because when there is a conflicting law between a specific and common law, the more specific rules must be applied. ${ }^{43}$

Nowadays, for the sake of society's right and law certainty toward certain acts experienced by the society, the judge of the State Court tries to overcome the problem of interfaith marriage as a legal innovation to fulfill the rule of the Nation based on UU Adminduk, that is to register every marriage in order to give protection. This is contradictory and not easy to avoid. The developing of law structure should conform with the basis of what J.W Harris calls as "the rule systemizing logic of legal science" that consist of four principles: exclusion, subsumption, derogation, and non-contradiction. ${ }^{44}$ Even though they are believed to be able to cover the independent legislation, the definition of independent legislation itself should be defined broadly that it can also include the legislation in the aspect of marriage and population administration and its implementation to the court. With those principles, a rule or norm should be able to be identified exclusively as a law or non-law. Subsumption has

43 Sudikno Mertokusumo, Penemuan Hukum Sebuah Pengantar (Yogyakarta: Liberty, 2009), p. 7.

${ }^{44}$ Shidarta, Hukum Penalaran dan Penalaran Hukum (Yogyakarta: Genta Publishing, 2013), p. 175; J.W. Harris, Law and Legal Science: An Inquiry Into the Concepts Legal Rule and Legal System (Oxford: Oxford University Press, 1979), p. 10. 
a meaning that legal system knows about the hierarchy and conform to the system. It also agrees with derogation that every rule does not want any conflict in the system. The last principle that is very important is non-contradiction principle which means, that two contradictive laws/ rules determine an obligation which could not be presented with nonobligation. However, it seems that when following the judicial reasoning of the judge in conducting a legal reasoning toward interfaith marriage permission, it is seen that the judge can not being able to really apply the principle of non-contradiction.

\section{The Poblem of Legal Uncertainty and the Significance of Legal Interpretation}

\section{The void of Law and Legal Uncertainty}

So far, most of law experts such as practitioners and theorists said that after UUP was constituted, there is a vacuum of law concerning an interfaith marriage. According to the researcher, there is no vacuum of law in the marriage law related to interfaith marriage. ${ }^{45}$ Arguments about the vacuum of law in it are inacceptable. The reason is because UndangUndang Perkawinan is a constitution that gives a legality of marriage to each religion. The basis of this law are: (1) Article 2 Verse (1) UUP says, "Marriage is legal if it is done based on law of each religion and faith"; (2) Article 8 and letter (f) says that marriage is banned between the two if their religion or other rules ban them to marry because of some reasons.

When there is a vacuum of laws, a legal innovation is generally made ${ }^{46}$ through a method of law construction. There are four construction

45 The vacuum of law (rechtsvacuum) means a state where there is no law or rule, or particularly there a vacuum of rules or constitution (wetvacuum) toward something. See. Jazim Hamidi, Hermeneutika Hukum (Malang: UB Press, 2011), p. 39.

46 Some law experts said different opinion regarding a legal innovation, a legal construction and a legal creation. When there is no rule, law or constitution about that, then a judge has an obligation to form the law, so there is no a vacuum of law. It leads to a legal construction term. While, the term of legal innovation have a connotation to a state where there is a law (on certain case), so the judge only apply it in a concrete case. A term of legal creation refers to a state where the law has already existed, but there are also different views of the experts about the methods and the way of law invention. 
methods ${ }^{47}$ that is commonly used by the judges (especially civil law) in a legal innovation: a method of argumentum per analogiam, a method of argumentum a contrario, a method of narrowing/validity of law and fiction of law. ${ }^{48}$ In the context of interfaith marriage, law construction method is not suitable, because in fact there is no vacuum of law in it.

To analyze this inaccuracy, it is better to do more research and analysis about the practices of the legal/law finding that has been done so far, especially related to the practice of interfaith marriage which get a legal statement from the State Court. Here are some citation about some legal considerations given by the State Court that decided to approve the request of interfaith marriage.

First, the judge of the State Court in its consideration stated that, "the forbiddance of marriage in Article 8 UU number 1 year 1974 about marriage does not strictly regulate (does not ban) a marriage of couple with different religion". This consideration can be seen in the Decree of Surakarta State Court (Penetapan Pengadilan Negeri Surakarta) Number 111/ Pdt P2007/PN. Ska, Resolution Number 112/PdtP/2008PN.Ska, Decree No. 115/Pdt.P/2008/PN.Ska, Decree No. 79/Pdt.P/2009/PN.Ska, Decree No. 92/Pdt.P/2010/PN.Ska, Decree No. 156/Pdt.P/2010/PN. Ska, Decree No. 04/Pdt.P/2011/PN. Ska, Decree No. 04/Pdt.P/2012/ PN.Mgl, Decree No. 90/Pdt.P/2011/PN. Ska, Decree 237/Pdt.P/2012/ PN.Ska. The understanding of the judges of the State Court towards the Article 8 UUP was separated and out from the understanding of other articles. Ideally, an understanding and interpretation towards a rule must be comprehensive as a whole system. Thus, when doing an interpretation toward Article 8 UUP, it should be related to the stipulation of other articles or other relevant rules.

When the Marriage Law (Undang-Undang Perkawinan) conditions that marriage should reflect the value of religiosity of the spouse, then having a faith is a condition sine qua non for couples that are going to marry. ${ }^{49}$

47 Sidharta, Hukum Penalaran dan Penalaran Hukum (Yogyakarta: Genta Publishing, 2013), pp. 172-3.

48 M. Sudikno Mertokusumo, Bab-Bab tentang Penemuan Hukum (Bandung: Citra Aditya Bakti, 1993), pp. 21-8.

49 Ratno Lukito, Hukum Sakral dan Hukum Sekuler Studi Tentang Konflik dan Resolusi dalam Sistem Hukum Indonesia (Jakarta: Pustaka Alvabet, 2008), p. 421. 
Article 2 verse (1) UUP states clearly that a marriage is only legal if it is based on the rule or law of the religion of the couples. Here, marriage is not only seen as a secular and individual matter of the couple, but also an institution under the Divine values. By admitting the importance of the religion's role in a marriage, the State exactly admits the role of religious law in forming a family. ${ }^{50}$ The literal interpretation of Article 2 verse (1) that a marriage can be legal "if it is based on each spouse's religion" can be considered as a formal banning of interfaith marriage. The marriage law in Islam for example, consists of elements that do not exist in the Christian tradition and vice versa. Thus, interfaith marriage is against the law. Since a marriage relation in Indonesia is only understood as a contract of two persons from the same religion, the marriage between spouse from different religion is formally an exception.

Second, the consideration of judges of State Court that states Chapter XIV Closing (Ketentuan Penutup) Article 66 which stated "for a marriage and any related to it is based on this law. With the validity of this law, the stipulation that is legislated by the Civil Law (Kitab UndangUndang Hukum Perdata - Burgerlijk Weboek), Ordonantie of Christian Indonesia Marriage (Huwelijks Ordonantie Christe Indonesiers S. 1933 No. 74, The Rule of Mixed Marriage (Regeling op de gemengde Huwelijken S. 1898 No. 158) and other rules related to marriage are stated as invalid. Since the Marriage Law / UUP No. 1 year 1974 does not clearly regulate a marriage of people with different religion, the stipulation concerning the mixed marriage in The Rule of Mixed Marriage (Regeling op de gemengde Huwelijken S. 1898 No. 158) can be applied in the case of marriage by people who still want to keep their religion. This can be seen in the consideration of judges in the lawsuit No. 111/Pdt.P/2007/PN. Ska, Lawsuit No. 112/Pdt.P/2008/PN.Ska, Lawsuit No. 115/Pdt.P/2008/ PN. Ska, and Lawsuit No. 79/Pdt.P/2009/PN.Ska.

The judge's consideration in applying the Rule of Mixed Marriage S. 1898 No. 158, is considered inconsistent with the purpose of the legislation of UU No. 1 year 1974 about Marriage. As what commonly legislated by the Government of Netherlands East Indie Colony, the Rule of Mixed Marriage S. 1898 No. 158 is secular, which regards a marriage

50 Ibid., p. 422. 
only by its civil law. ${ }^{51}$ Based on the view of Western Civil law, a legal marriage is a marriage that is registered in the Civil Registrar Office. A marriage that is registered only by religious law is considered illegal. In the article of 530 Civil Law/ KUHP, there is even a rule that ban the religious officer to arrange a marriage by religious law before it is done by the Civil Law. ${ }^{52}$ This is certainly contrary with the mission and vision of the legislation of the Marriage Law that is to eradicate secularism from marriage law in Indonesia and to relate marriages with the Divine values that is based on "the one and only God/Ketuhanan Yang Maha Esa". Here, every law which does not agree with the value and principle of Pancasila (esp. the first sila) must not be used anymore.

The other point of Mixed Marriage Law S. 1898 No. 158 is that it must follow the law of the husband. If the judge of the State court still refers to the law of Mixed Marriage Law S. 1898 No. 158 and be consistent with it, a mixed marriage should be based on the religion of the groom; no matter what his religion is. However, in fact, interfaith marriage through the State Court decision, doesn't necessarily follow the religion of the groom, yet the State court still registers it in the Civil Registrar Office. The unanswerable question actually lies in, which marriage law can be applied and how a marriage is conducted. Here, there is an inconsistency of interfaith marriage done by the State court. Marriage as an act of law has not been done yet, but there is a command from the State Court to Civil Registrar Office to register it. So, what must be registered if the marriage itself has not even been done yet?

\section{The Significance of Legal Interpretation for the Legal Certainty}

Refer to the mission and vision of the legislation of Marriage Law (UUP), that is to remove secularity and related it to values of the first sila of Pancasila. The assumption that UUP does not regulate the interfaith marriage must be rejected, since it is not apt to the philosophical values of UUP itself. The best way that must be done by law experts and law practitioners, especially the judge of State Court, is to do a legal

51 Subekti, Pokok-Pokok Hukum Perdata (Jakarta: PT Intermasa, 1992), p. 23.

52 Ali Afandi, Hukum Waris Hukum Keluarga Hukum Pembuktian Menurut Kitab Undang Undang Hukum Perdata (Jakarta: Bina Aksara, 1986), p. 98. 
/law interpretation instead of doing a law finding. It is called as legal interpretation because in fact there has been a law that implicitly cope with interfaith marriage. It is because interfaith marriage has been stated in some articles of the UUP.

The methods of legal interpretation that can be applied in interfaith marriage are systematic interpretation and historical interpretation. Systematic Interpretation is an interpretation that relates a rule with the other rule. ${ }^{53}$ Reading a stipulation of a constitution, it must not be separated from the other stipulation. A stipulation must be examined from its relation with the other stipulation in a whole system. Interpreting a stipulation is in order to get a truth. In relation to interfaith marriage, systematical interpretation should have been applied either because of its relation with the other article or because of its relation with the constitution of its kind that is related with religious law.

Another interpretation that can be used is historical interpretation. It is an interpretation which sees the historical background of a law or the history of a certain law formulation. ${ }^{54}$ Constitution is a respond or a reaction towards the social need of society that organize life and the habit of the society which could be seen and explained from its history. Every rule can be regarded as a step of the development of the society whose definition can be explained by researching the previous steps.

According to Mertokusumo, historical interpretation is divided into historical interpretation of constitution (wetshistorisch) and historical interpretation of law (rechtshistorisch). ${ }^{55}$ If those interpretation is based on the meaning and purpose of the constitutional formulation by exploring the result of the document and talks of the House of Representative (DPR) that forms a certain rule, it is called historical interpretation of constitution. Related to this, it is necessary to see the historical background of the legislation of UUP which was nationally legislated based on UU No. 1 Year 1974.

On the other hand, historical interpretation of law is an interpretation that specifically tries to investigate why and how a legal institution was formed. This interpretation can be applied to interpret the

\footnotetext{
53 Mertokusumo, Bab-Bab tentang Penemuan Hukum, pp. 60-1.

54 Sidharta, Hukum Penalaran dan Penalaran Hukum, p. 170.

55 Mertokusumo, Bab-Bab tentang Penemuan Hukum, p. 60.
} 
existence of marriage institution in the version of UUP, the existence of marriage registrar institution in the UUP, and also its relation with other institution such as the existence of the State Court legislation toward interfaith marriage in the era before and after the formulation of UUP. It is because every legal institution has its own history.

\section{E. Concluding Remarks}

Based on the above explanation, the researchers conclude that there is no vacuum of law concerning the interfaith marriage in which there should be a law finding through a law construction method. In fact, there has been a rule about interfaith marriage which is implicitly based on each religious law, as the method applied by the Judges.

Interfaith marriage based on the stipulation of State court is seen legitimated as long as its marriage follows the ritual/rule of one of the spouse's religious belief. Concerning the marriage registration toward events or law acts experienced by the society as stated by UU Population Administration, there has not been synchronization with the rules of marriage law which has an implication toward non-contradiction principle in the formulation of law structure. Here, when the marriage is based on the stipulation of the State Court but not following the ritual or rule of certain religion belief, it implies not only to a tendency 'smuggling' of law by the people but also to the judges conflicting when having a decision related to judicial reasoning.

Even though marriage is included in private law, the law itself is regulative and imperative. It means that a marriage must follow the law where it is done (the principle of lex loci celebrationis). On the other hand, the State has the obligation to protect their citizens through the efforts of registration for the sake of orderly administration and for law certainty. However, the legal establishment should subject to the principle of exclusion, subsumption, derogation and non-contradiction, so that implementation and its implications for society are not counterproductive.

Normative review towards interfaith marriage registration is similar, that is to follow the understanding of their legal status. For the group who understand textually, states that the marriage does not need to be listed. While the group who understand contextually says that interfaith marriage should be registered in order to have legal consequence. 
Normatively, it can be concluded that (1) marriage is a public affair that should be known by any parties directly or indirectly, (2) there is a recognition and guarantee of rights, and (3) the recognition and guarantee of rights emerge in the form of the announcement and the existence of witness in a marriage. These three main things may change if they are contextualized with the present time. In the era of the Prophet Muhammad saw, the recognition and guarantee of the rights is obtained through announcements and witnesses in the marriage. While in the current context, the recognition and guarantee of rights is based on administrative and constitutional system that lead to the need for a written document. As a result, marriage certificate is now becoming a recognition and guarantee of the rights acquired by a married persons. 
Ermi Suhasti, et al.

\section{BIBLIOGRAPHY}

Afandi, Ali, Hukum Waris Hukum Keluarga Hukum Pembuktian Menurut Kitab Undang Undang Hukum Perdata, Jakarta: Bina Aksara, 1986.

Dianti, Novina Eky, "Sinkronisasi Peraturan Perundang-undangan Tentang Pencatatan Perkawinan Beda Agama di Kota Surakarta", Master's Thesis, Yogyakarta: Universitas Gadjah Mada, 2016.

"Empat Cara Penyelundupan Hukum Bagi Pasangan Beda Agama", bukumonline.com, 2006, https://www.hukumonline.com/berita/baca/ hol15655/empat-cara-penyelundupan-hukum-bagi-pasangan-bedaagama, accessed 14 Aug 2017.

Febrian, Gugat UU Pernikahan ke MK Agar Menikah Beda Agama Ada Kepastian Hukum - Kompas.com, https://nasional.kompas.com/ $\mathrm{read} / 2014 / 09 / 04 / 19394581 /$ Gugat.UU.Pernikahan.ke.MK.Agar. Menikah.Beda.Agama.Ada.Kepastian.Hukum, accessed 4 Sep 2014.

Hamidi, Jazim, Hermeneutika Hukum, Malang: UB Press, 2011.

Hamka, Tafsir Al-Az̧har, vol. V, Singapura: Pustaka Nasional Pte Ltd, 2003.

Harris, J.W., Law and Legal Science: An Inquiry Into the Concepts Legal Rule and Legal System, Oxford: Oxford University Press, 1979.

Ibn Katsir, Abu'l-Fida Isma’il, Tafsir Al-Qur'an Al-Adz̨im, Beirut: Dar al-Fikr, 1997.

Indrayanti, Kadek Wiwik et al., "Juridical Implications of the Legal Norm Void of Interfaith Marriages in Indonesia", Brawijaya Law Journal, vol. 4, no. 1, 2017, pp. 129-43 [http://dx.doi.org/10.21776/ ub.blj.2017.004.01.07].

Jaziriy, Abdurrahman al-, al-Fiqh "ala Mazabib al-Arba" ah, vol. 4, Beirut: Dar al- Ihya al- Turas al- 'Arabi, 1969.

Karsayuda, M., Perkawinan Beda Agama: Menakar Nilai-Nilai Keadilan Kompilasi Hukum Islam, Yogyakarta: Total Media, 2006.

“Kompak Tolak Nikah Beda Agama”, Jpnn.com, https://www.jpnn.com/ news/kompak-tolak-nikah-beda-agama, accessed 13 Sep 2014.

Lukito, Ratno, "The Enigma of Legal Pluralism in Indonesian Islam: The Case of Interfaith Marriage", Journal of Islamic Law and Culture, vol. 10, no. 2, 2008, pp. 179-91 [http://dx.doi. 
org/10.1080/15288170802236457].

----, Hukum Sakral dan Hukum Sekuler Studi Tentang Konflik dan Resolusi Dalam Sistem Hukum Indonesia, Jakarta: Pustaka Alvabet, 2008.

Maraghi, Ahmad Mustafa, Tafsîr al-Marâghi, vol. VI, Cairo: Mathba'ah al-Halabiy, 1946.

Mertokusumo, M. Sudikno, Bab-Bab tentang Penemuan Hukum, Bandung: Citra Aditya Bakti, 1993.

Mertokusumo, Sudikno, Penemuan Hukum Sebuah Pengantar, Yogyakarta: Liberty, 2009.

Monib, Mohammad and Ahmad Nurcholish, Kado Cinta Bagi Pasangan Nikah Beda Agama, Jakarta: Gramedia Pustaka Utama, 2008.

MUI, Himpunan Fatwa MUI Sejak 1975, Jakarta: Erlangga, 2011.

Mustafid, Fuad, "Perkawinan Beda Agama dan Kebebasan Individual Manusia dalam Islam: Perspektif 'Teori Naskh' Mahmoud Muhammad Thaha", Musãwa Jurnal Studi Gender dan Islam, vol. 10, no. 2, 2011, pp. 229-48 [http://dx.doi.org/10.14421/ musawa.2011.102.229-248].

Nasution, Khoiruddin, "Pencatatan Perkawinan Beda Agama: Tinjauan Normatif", presented at the National Seminar of Contemporary Law of Islamic Family in Indonesia, Yogyakarta, 2015.

Nurlaelawati, Euis, "For the Sake of Protecting Religion: Apostasy and its Judicial Impact on Muslim's Marital Life in Indonesia", Journal of Indonesian Islam, vol. 10, no. 1, 2016, pp. 89-112 [http://dx.doi. org/10.15642/JIIS.2016.10.1.89-112].

Parolin, Gianluca P., "Interfaith Marriages and Muslim Communities in Scotland: A Hybrid Legal Solution?", Electronic Journal of Islamic and Middle Eastern Law (EJIMEL), vol. 3, no. 17, 2015, pp. 83-96 [http://dx.doi.org/info:doi/10.5167/uzh-110597].

"PGI Anggap Larangan Nikah Beda Agama Melanggar HAM", www. jpnn.com, 2014, https://www.jpnn.com/news/pgi-anggap-larangannikah-beda-agama-melanggar-ham, accessed 5 Nov 2014.

Qudāmah, 'Abd Allāh ibn Aḥmad Ibn, Al-Sharh al-Kabîr 'alâ Matn alMughnî, vol. VII, Beirut: Dār al-Fikr, 1984.

Ridha, Muhammad Rasyîd, Tafsir al-Manar, vol. VI, 1st edition, Beirut: 
Dâr al-Kutub al-'Ilmiyyah, 1947.

Sewenet, Alex Minichele, Fasil Merawi Tessagaye, and Getnet Tadele, "Interreligious Marriage: Social and Religious Perspectives", Imperial Journal of Interdisciplinary Research, vol. 3, no. 6, 2017.

al-Shâbûni, Muhammad 'Ali, Tafsîr Ayyât al-Abkâm, vol. I, Cairo: Dâr alShâbûni, 2007.

Shidarta, Hukum Penalaran dan Penalaran Hukum, Yogyakarta: Genta Publishing, 2013.

Shihab, M. Quraish, Tafsir Al Misbah, vol. 3, Jakarta: Lentera Hati, 2006.

Sidharta, Hukum Penalaran dan Penalaran Hukum, Yogyakarta: Genta Publishing, 2013.

Subekti, Pokok-Pokok Hukum Perdata, Jakarta: PT Intermasa, 1992.

Suhasti, Ermi, Harmoni Keluarga Beda Agama, Research Report, Yogyakarta: Lemlit UIN Sunan Kalijaga, 2009.

----, "Harmoni Keluarga Beda Agama di Mlati, Sleman, Yogyakarta", Asy-Syir'ah, vol. 45, no. 1, 2011, pp. 1233-54 [http://dx.doi. org/10.14421/asy-syir'ah.2011.\%x].

Suhasti, Ermi and Hartini, "Shifting Meaning of the Sacred Value of Marriage (Study on the Practice of Interfaith Marriage Through the Establishment of the District Court)", presented at the International Conference Legal Reform in Indonesia: Towards Justice, Yogyakarta, 6 Sep 2017.

Suwarta, "Pandangan Praktisi Terhadap Pencatatan Perkawinan Beda Agama", Pandangan Terbadap Polemik Perkawinan Beda Agama, Yogyakarta, 10 Oct 2015.

Syafi'i, Nasrul Umam and Ufi Ulfiah, Ada Apa Dengan Nikah Beda Agama?, Jakarta: Qultum Media, 2004.

Wahyuni, Sri, "Pelaksanaan Perkawinan Campur Beda Agama antara Warga Melayu Malaysia dan Dayak Kalimantan di Daerah Perbatasan Sambas Kalimantan Barat antara Living Law dan Hukum Positif Indonesia", Al-Ahwal: Jurnal Hukum Keluarga Islam, vol. 9, no. 1, 2017, pp. 31-46 [http://dx.doi.org/10.14421/ahwal.2016.09103].

Wasman and Wardah Nuroniyah, Hukum Perkawinan Islam di Indonesia:

Perbandingan Fiqib dan Hukum Positif, Yogyakarta: Teras, 2011. 